\title{
Discovery of 2-Aminothiazole Derivatives as Antitumor Agents
}

\author{
Minghua Li, Yoojin Sim, and Seung Wook Ham* \\ Department of Chemistry, College of Natural Science, Chung-Ang University, Seoul 156-756, Korea \\ *E-mail:swham@cau.ac.kr \\ Received March 2, 2010, Accepted April 5, 2010
}

Key Words: Aminothiazole, Antitumor agents, Apoptosis, MTT assay

Thiazole derivatives are present in many natural and synthetic products with a wide range of pharmacological activities, such as anticancer, antiviral, antibacterial, antifungal, and anti-inflammatory activities. ${ }^{1}$ Among them, 2-aminothiazole derivatives possess an antitumor activity through the inhibition of the kinases. ${ }^{2-4}$

In the course of searching for anticancer agents, 2-aminothiazole derivatives were recently prepared by varying the 2-amino position and the 5-substituted group of the 2-aminothiazole core in a high-speed parallel format using the procedure that was described in the literature. ${ }^{5}$ The variations in the 5-position of the 2-amino-1,3-thiazole core were carried out though the condensation of thiourea and the chloroaldehydes, which were commercial available or were obtained using NCS in the presence of the proline catalyst. ${ }^{6}$ For the acylamino portion variations, the acylation was achieved using various carboxylic acids in Scheme 1.

The cytotoxic activities of these materials were directly investigated against the Hep3B cells. Thus, the Hep3B cells were seeded at $2 \times 10^{5}$ cells $/ \mathrm{mL}$ in a 6 -well plate and treated with $10 \mu \mathrm{M}$ of several hundred compounds from the chemical library. After the cells were briefly observed after treatment for 24 , 48,72 hours for the selection of the effective compounds, the effective compounds were used to perform the 3-(4,5-dimethylthiazol-2-yl)-2,5-diphenyltetrazolium bromide (MTT) assays at various concentrations for 48 hours in order to determine the inhibitory potency. ${ }^{7}$ The Hep3B cells were seeded at a density of $3 \times 10^{4}$ cells $/ \mathrm{mL}$ in a 24 -well plate. After incubation with various concentrations of the compounds, the cell viability was determined through the addition of $300 \mu \mathrm{L}$ of the $1 \mathrm{mg} / \mathrm{mL}$ MTT working solution for $5 \mathrm{~h}$ in the dark. Crystal formazan was dissolved in DMSO, and the absorption wavelength of $570 \mathrm{~nm}$ was determined for each well in the plate with a reference wavelength of $690 \mathrm{~nm}$. Interestingly, the data were fit to a sigmoid nonlinear regression model, and $50 \%$ of the cells were viable. $\mathrm{IC}_{50}$ was calculated on the basis of the best-fit model, and compound $\mathbf{2} \mathbf{d}$ revealed a significant inhibition effect, with an $\mathrm{IC}_{50}$ value of $0.040 \mu \mathrm{M}$.

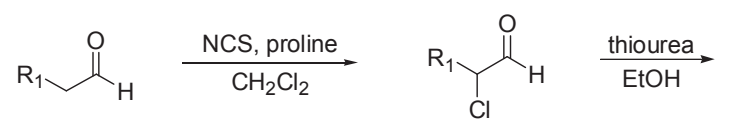

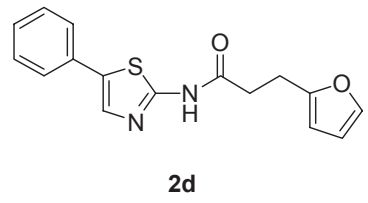

A $100 \mathrm{nM}$ concentration of compound $\mathbf{2 d}$ was added to the subconfluent cultures of the Hep3B cells, and the cell morphology and the DNA damage were examined for a total 72 hours in order to test the cell killing effect of the compound. In Figure 1, the treatment of compound $\mathbf{2 d}$ caused the clear DNA ladder formation in a time-dependent manner. The DNA laddering of the nucleosomal size was revealed in the cells that were treated with compound $\mathbf{2 d}$, suggesting that the population of the cells underwent an apoptotic cell death. ${ }^{8}$ Two types of cell changes, a cell shrinkage followed by detachment and a ghostlike necrosis without shrinkage and detachment, were observed. Microscopically, a small number of the typical apoptotic cells,

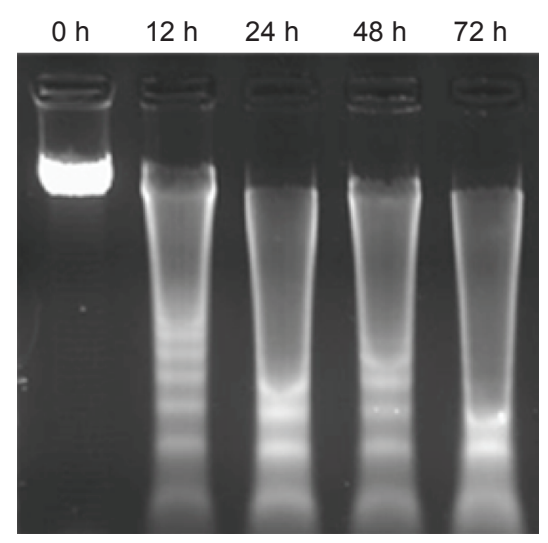

Figure 1. The cells that were grown at a density of $2 \times 10^{6}$ cells $/ \mathrm{mL}$ in a $100 \mathrm{~mm}$ dish were exposed to compound $\mathbf{2 d}(100 \mathrm{nM})$ at various periods of time. The genomic DNA was prepared using the Wizard Genomic DNA Purification Kit (Promega, Madison, WI). The DNA was precipitated with isopropanol, separated in a $1.5 \%$ agarose gel and visualized using UV illumination after the ethidium bromide staining. 
Table 1. $\mathrm{IC}_{50}$ values of the various aminothiazole derivatives against the Hep3B cells

$$
\mathrm{R}_{\mathrm{N}}^{\mathrm{S}} \stackrel{\mathrm{N}}{\mathrm{C}} \mathrm{R}_{\mathrm{R}_{2}}
$$

\begin{tabular}{|c|c|c|c|}
\hline Compound & $\mathrm{R}_{1}$ & $\mathrm{R}_{2}$ & $\mathrm{IC}_{50}(\mu \mathrm{M})$ \\
\hline $1 \mathbf{a}$ & \multirow{4}{*}{ Methyl } & $n$-Propyl & No inhibition \\
\hline $1 b$ & & $n$-Nonyl & No inhibition \\
\hline 1c & & 2-Furyl & No inhibition \\
\hline 1d & & $\mathrm{CH}_{2} \mathrm{CH}_{2}$-2-Furyl & 1.08 \\
\hline $\mathbf{2 a}$ & \multirow{4}{*}{ Phenyl } & $n$-Propyl & $>50$ \\
\hline $2 b$ & & $n$-Nonyl & 21.50 \\
\hline $2 \mathrm{c}$ & & 2-Furyl & No inhibition \\
\hline $2 d$ & & $\mathrm{CH}_{2} \mathrm{CH}_{2}$-2-Furyl & 0.040 \\
\hline $3 \mathbf{a}$ & \multirow{4}{*}{$\mathrm{CH}_{2}$-Phenyl } & $n$-Propyl & $>50$ \\
\hline $3 \mathbf{b}$ & & $n$-Nonyl & 38.80 \\
\hline $3 c$ & & 2-Furyl & No inhibition \\
\hline 3d & & $\mathrm{CH}_{2} \mathrm{CH}_{2}$-2-Furyl & 0.089 \\
\hline $4 a$ & \multirow{4}{*}{$\mathrm{CH}_{2} \mathrm{CH}_{2}$-Phenyl } & $n$-Propyl & $>50$ \\
\hline $4 b$ & & $n$-Nonyl & $>50$ \\
\hline $4 c$ & & 2-Furyl & No inhibition \\
\hline $4 d$ & & $\mathrm{CH}_{2} \mathrm{CH}_{2}$-2-Furyl & 2.02 \\
\hline
\end{tabular}

The $\mathrm{IC}_{50}$ values are reported as the mean of at least two independent measurements with the calculated standard error. Each $\mathrm{IC}_{50}$ was determined from a six point dose-response curve that was run in triplicate.

namely the shrunken cells with fragmented nuclei (apoptotic bodies), were observed among the cells that were treated with the potent growth inhibitory compounds, and most of them were positively stained using the in situ end labeling techniques (data not shown). The number of apoptotic cells that appeared $24 \mathrm{~h}$ after the treatment were counted, and this number was largely parallel to the potency of the growth inhibition of the compound. However, the ghost-like necrosis predominated when more potent compounds were used at higher concentrations $(10 \mu \mathrm{M})$.

A number of 2-aminothiazoles were also prepared in order to investigate the SAR of the inhibitory potency of compound 2d. When the compounds were evaluated in order to examine the antiproliferative effects in the Hep3B cell $48 \mathrm{~h}$ cytotoxicity assay, the 2-furylethanolyl group clearly provided the best inhibitory potency among the various acyl groups, whereas the phenyl or benzyl group provided better results than the other 5-substituted groups in Table 1.

Previous reports have shown that 2-aminothiazole derivatives possess inhibitory activities against the kinases, such as CDKs, by competing at the ATP binding site. ${ }^{2-4}$ Therefore, the 2-aminothiazole derivatives were screened with respect to the kinase inhibition. However, none of these compounds exhibited a good inhibitory efficacy for several kinases, as well as CDK2. Nevertheless, the observed antiproliferative activity was believed to be exerted through a specific cellular target because the introduction of the substituent groups on the aminothiazole caused differences in the cellular antiproliferative activity. Therefore, the cellular mechanism of the action of this compound is currently being investigated.

Acknowledgments. This work was supported by the ChungAng University (2009).

\section{References and Notes}

1. Conrath, U.; Pieterse, C. M.; Mauch-Mani, B. Trends. Plant Sci. 2002, 7, 210.

2. Kim, K. S.; Kimball, S. D.; Misra, R. N.; Rawlins, D. B.; Hunt, J. T.; Xiao, H. Y.; Lu, S.; Qian, L.; Han, W. C.; Shan, W.; Mitt, T.; Cai, Z. W.; Poss, M. A.; Zhu, H.; Sack, J. S.; Tokarski, J. S.; Chang, C. Y.; Pavletich, N.; Kamath, A.; Humphreys, W. G.; Marathe, P.; Bursuker, I.; Kellar, K. A.; Roongta, U.; Batorsky, R.; Mulheron, J. G.; Bol, D.; Fairchild, C. R.; Lee, F. Y.; Webster, K. R. J. Med. Chem. 2002, 45, 3905.

3. Misra, R. N.; Xiao, H. Y.; Kim, K. S.; Lu, S.; Han, W. C.; Barbosa, S. A.; Hunt, J. T.; Rawlins, D. B.; Shan, W.; Ahmed, S. Z.; Qian, L.; Chen, B. C.; Zhao, R.; Bednarz, M. S.; Kellar, K. A.; Mulheron, J. G.; Batorsky, R.; Roongta, U.; Kamath, A.; Marathe, P.; Ranadive, S. A.; Sack, J. S.; Tokarski, J. S.; Pavletich, N. P.; Lee, F. Y.; Webster, K. R.; Kimball, S. D. J. Med. Chem. 2004, 47, 1719.

4. Borzilleri, R. M.; Bhide, R. S.; Barrish, J. C.; D'Arienzo, C. J.; Derbin, G. M.; Fargnoli, J.; Hunt, J. T.; Jeyaseelan, R. Sr.; Kamath, A.; Kukral, D. W.; Marathe, P.; Mortillo, S.; Qian, L.; Tokarski, J. S.; Wautlet, B. S.; Zheng, X.; Lombardo, L. J. J. Med. Chem. 2006, $49,3766$.

5. Helal, C. J.; Sanner, M. A.; Cooper, C. B.; Gant, T.; Adam, M.; Lucas, J. C.; Kang, Z.; Kupchinsky, S. Ahlijanian, M. K.; Tate, B.; Menniti, F. S.; Kelly, K.; Peterson, M. Bioorg. Med. Chem. Lett. 2004, 14, 5521.

6. Halland, N.; Braunton, A.; Bachmann, S.; Marigo, M.; Jorgensen, K. A. J. Am. Chem. Soc. 2004, 126, 4790.

7. Minko, T.; Kopeckova, P.; Pozharov, V.; Kopecek, J. J. Controlled Release 1998, 54, 223.

8. Williams, G. T. Cell 1991, 65, 1097. 